\title{
The Construction of Female College Students Developmental Moral Education System Zhang Liping
}

\author{
(China West Normal University, Nan Chong,Sichuan,637002)
}

\begin{abstract}
Keywords: Female university students; Sexual knowledge; Moral education system
\end{abstract}
\begin{abstract}
With the progress of modern civilization, the view of emotion is also changing in our country, including colleges and universities female college students' marriage problems, which also gradually allows rational emotional communication, at the same time on the symbiotic development of material and spiritual needs, the openness of comprehensive moral education also gradually improves its basic work of the college life. To reduce some negative thoughts of female college students in college, strengthen its compulsory education so as to realize the all-round construction of education, and finally realize comprehensive construction system, and better promote female college students' comprehensive quality promotion.

Modern female college students' marriage view in society developing from social investigation, the main problem is that it is not very mature, and some of the ideas on standard concept are not very complete, and perception of emotional problems also is not able to fully realize their own needs. So based on comprehensive moral education, psychological teacher should give targeted marriage education to guide more mate choice criteria accord with their own standards, and complete effective construction of their all-round development.
\end{abstract}

\section{SAMPLING SURVEY METHOD}

In female college students' developmental moral education system, we made sampling survey analysis aimed at several universities with a total of 3000 questionnaires and 2758 effective recoveries. Its content involves multiple aspects like daily life, learning method, attitude toward life, the pursuit of love, sexual knowledge. Sample survey population age is between $19 \sim 25$ with an average of $21.6 \pm 1.2$. Mainly are college undergraduates, followed by junior college students, and part of graduate students.

\section{RESEARCH RESULTS}

Through research analysis, girls with love experience girl are 2011 people (72.92\%); girls having the thought of love, but did not take corresponding measures are 301 people $(10.91 \%)$; girls having one love experience are 625 people (22.66\%); girls having two love experiences are 721 (26.14\%); girls having more than three times love experience are 665 people $(24.11 \%)$. With consciousness liberation of modern society, the society reduced students' requirements. In university, they can free love, and people are not identical to partner's request. Through the research, most of the girls' attitude to love is to give it a try and get emotional sustenance, some are to find a life partner, a few are to look for emotional support, few are to show off their charm or satisfy their physiological needs. As a result of the change of students' self-awareness, situations change. Students' own pursuits have all made a tremendous change.

\section{ANALYSIS OF THE RESEARCH RESULT}

From the research analysis, such way of understanding results from the fundamental change of college students' cognition to themselves from the past read-only to for a better life, and plan for the future marriage at the same time. For the wait-and-see attitude, most girls are fuzzy on the concept of love, some who are unpleasant about the reality would consider net love, but net love 
phenomenon are rare. In this research, although some students think Internet dating is fun, but it is unreliable. This suggests that female college students love standard is valued, and they will not grab a net friend to ease loneliness if there is no ideal boyfriend.

College female students think that consumption should be paid equally. 5\% think that their boyfriends should pay for all the consumption; $15 \%$ think they should carry out AA; and nearly half of them think that they should undertake the consumption together, but need to pay according to their own economic strength, and about twenty percent of female college students think it doesn't matter. This suggests that female college students have been quite mature on consumer issues.

From the survey, most of the parents keep an open attitude during the period of school love. They think their children have reached the age of marriage, in the case of not affect learning, they can be in love. So it would also help the marriage in the future. But from the perspective of bear ability of university students, their treatment method of feelings still cannot be better effective processed, and the lag of the physiological capacity growth situation is still the cause of dis-affordable brokenhearted pain during their learning. Most female college students can't accept heartbroken, and even there will be a need for mental revenge, and there are some girls who may need a period of time to get used to it, and slowly recover. In such intense contradiction, female college students will choose concessions finally. Under the influence factors of society and family, their own emotion is obviously vulnerable, and the most important is its own naive, which is the most main source of these emotional crisis.

\section{COLlege STUDENTS' SEXUAL ATTITUDE AND ETHICAL ISSUES FROM THE VIEW OF PRESENT THOUGHTS AND ACTIONS}

Sex education shall be a main task of modern social education. Due to the reform and opening up in the last century, Chinese has had the very big progress from not talking about sex to accepting such a topic, but in this development, many people are still not civilized about the understanding of sex, and at the same time, some people are too open. To carries on the comprehensive analysis research on sex, start from the analysis of decisive social factors. Sex itself is to determine whether a family can complete the fundamental factors, not in order to solve happy props, which reflects a kind of responsibility in order to obtain permanent happiness, and people need to correct view of sex. Modern colleges students fall in love and have sex, such phenomenon have become so common. Even there are men and women lovers live together, which shows that modern college students' attitude toward sex has changed greatly. Of course, there are conservatives who believe premarital sex is immoral, but the proportion is smaller. Most of the female college students accept sex before marriage. Under the impact of new social cultural background, the traditional marriage morality is under huge impact.

From modern female college students' understanding of sex knowledge, most of the women have realized the importance of sex, and are able to look at these behaviors according to the psychological needs of themselves. In love, they take safety protection measures in order to protect their own security. Under such an environment, most of the girls still have contradictory psychology attitude toward sex. In view of sex, they are often conservative. In the process of research, most of the girls don't know how to start sex life. In this research, only 5\% of girls know sexual knowledge. Under the condition of no corresponding social and family influence, most think sexual problem is not talk able, and should not be talked about in our daily life. Even there are a lot of parents remain very strong mentalities against receiving reproductive education. The spread of modern college students' sexual knowledge has a lot of obstacles. The lack of sexual knowledge is the reason of a large number of abortions and young women infertility condition.

In female college students moral bottom line investigation, on the problem of being kept on, more than seventy percent of female college students are against being kept concubines, and think this is a kind of bad performance, but some people think that belongs to a kind of individual phenomenon and can understand. Female college students' cognition of self will be better able to locate for them. Although the understanding of sex knowledge is still incomplete, the enlightenment 
of social moral problems can be got through their own ideological cognition and help to carry on some simple explanation for the surrounding friends. For sexual knowledge propagation, most female college students think they have not got effective education in university. In emotional communication, as a result, this is the most important question leading to great physiological and psychological problems.

\section{PRESENT COLLEGE FEMALE STUDENTS' MORAL EDUCATION REFORM PROPOSALS}

In modern female college students' education in colleges and universities, we should strengthen the education of moral education problems to promote the reform system. Through comprehensive moral education, realize the affirmation of the value of oneself, and to enhance female college students' social cognition, and eventually improve their moral quality, at the same time, complete the ideas of graduation and employment problem.

In the process of college students' moral education reform, first of all, carry on ideological education, and let them to realize the transformation of the society, and be able to find their life request working in modern social life. Female college students have to cultivate free-standing self-improvement social responsibility consciousness, and do not rely on mate or partner. Analysis according to the comprehensive analysis of the society development, more effectively complete the understanding of work life. Secondly, on the view of social and family, correct the view of the standard of mate choice, and according to their own personal circumstances, choose more appropriate dating goals, and in accordance with the life responsibility, get spiritual life enjoyment. Finally, put an end to the material value enjoy thoughts, lead a healthy social life, and put an end to the germ of greed.

In university teaching of modern society, the most major problem facing is that in continuously expanding enrollment and mixed admissions process, how to ensure the quality of students, how to ensure the quality of graduates, and solve the problem of modern college students' employment. Its own survival environment for college students' correct cognition, and from healthy normal thought thoroughly change cognitively, so as to achieve comprehensive self-growth of moral education.

\section{EDUCATION OUTLOOK AFTER THE HIGH QUALITY EDUCATION IMPLEMENTATION OF MORAL EDUCATION SYSTEM}

According to the social problems in recent years, strengthen sex knowledge education of female college students and improve the system of moral education for college students is a basic approach to improve the quality of graduates. In order to promote quality assurance in modern education system reform in our country, we should let female college students recognize the relationship between love and career, and starting from their own interests, realize the premarital love standards, and according to the environmental awareness of marriage education, realize the cognition of modern system of social survival. At the same time of reflecting their social value, ensure their relative rights and interests in society. According to the organic moral structure standards, strengthen their own moral cognition ability. Distinguish between right and wrong, and better achieve corresponding social high quality life. Find their life partners meeting their requirements.

The school should take responsibility for female college students moral education, and combine with the development of modern society values, better guide the development of female college students' moral education in the normal course of study, correct their understanding of positive and negative of sexually transition, and be able to have the correct understanding of love in the process of learning and based on the reality of society, get on the right track.

\section{CONCLUSION}

The security problems of female college students' moral education is an important research standard in our country modern society's survival and development. Woman's social ethics awareness is the bottom line of social thought in our country. If they have cognitive deviation, there 
is a great problem which will directly affect the stability of social and cultural development. From the perspective of rationality of social development, strengthen the education on college students' moral knowledge can better promote their positive thinking and reduce support for wrong views. This is the most powerful way to reduce unstable social factors. Through all aspects of moral education in modern university education, accelerate the development of modern college students' moral cognition, better promote the harmonious development of the modern society, and finally realize the great unity society.

\section{REFERENCES}

[1] Zhang Sanping. Analysis of 1000 cases of only-child college students personality and enlightenment [D]. Wuhan University of Technology, 2002.

[2] Wang Dexiang. Contemporary college students' thought morals education problems [J]. China's Adult Education, 2004, (1) : 23 and 24.

[3] Yao Bei. Only children in our country college students' moral quality problem analysis and revelation [D]. Nanjing University, 2009.

[4] Sun Zhifei, Zhang Chunlou. Tradition and modern: the investigation and analysis of female students' opinions about love [J]. Journal of Jiangxi Normal College, 2014, (4) : 102-106.

[5] Chen Jing. Chongqing university sports education professional college students health values research [D]. Southwest University, 2007.

[6] Huang Weiping. Female college students correct outlook cultivation and education path research [J]. Science and Technology and Development of Enterprise, 2015, (9) : 136-137.

[7] Liu Jianxin. The investigation of college students' psychological health education---- Take Qufu Normal University as an example [D]. Shandong Normal University, 2007. 